\title{
Just-in-Time Teaching in Biology: Creating an Active Learner Classroom Using the Internet
}

\author{
Kathleen A. Marrs*t and Gregor Novak**
}

\begin{abstract}
*Department of Biology, Indiana University, Purdue University Indianapolis, 723 W. Michigan Street, Indianapolis IN 46202; and **Department of Physics, United States Air Force Academy, 2354 Fairchild Drive, Colorado Springs Colorado 80840
\end{abstract}

Received for publication November 21, 2003; accepted December 12, 2003.

\begin{abstract}
Just-in-Time Teaching (JiTT) is a teaching and learning approach that combines the best features of traditional in-class instruction with the communication and resource potential available via the Web. We describe here how JiTT can be used to teach biology to undergraduate and graduate level students, both science majors as well as nonscience majors. A key characteristic of JiTT is the creation of a feedback loop between the classroom and the Web using Internet "WarmUp" assignments that are due prior to class time. By examining student responses to Warm Up exercises before class, faculty members can determine the level of understanding, prior knowledge, and misconceptions that students bring to class. Classroom time can then be spent addressing these misconceptions while discussing course content. In class Cooperative Learning exercises reinforce course content in an informal group setting. Other features of JiTT, such as "What is Biology Good For," make clear the relevance of specific concepts in biology in society and increase student motivation. Assessment results have been positive, including decreased attrition rates, increases in student attitudes, interactivity, study habits, and cognitive gains in classrooms using JiTT.
\end{abstract}

\section{WHAT IS JiTT AND WHAT IS IT DESIGNED TO ACCOMPLISH?}

JiTT is a technique for teaching and learning that uses the Internet to improve student success in college science courses by enhancing and extending classroom instruction via the Web. JiTT is designed to bring pedagogically successful methods for teaching and learning into the classroom: interactive engagement (active learning), constructivism, and prompt feedback (formative assessment), described below. JiTT was originally developed at Indiana University Purdue University Indianapolis (IUPUI) and the United States Air Force Academy to help students and faculty in physics (Novak et al 1999). JiTT has since been expanded to other disciplines and universities and is currently being used in biology, geology, chemistry, psychol-

DOI: $10.1187 /$ cbe.03-11-0022

${ }^{+}$Corresponding author. E-mail address: kmarrs@iupui.edu. ogy, and math, as well as in nursing, history, economics, and anthropology. JiTT has been adopted by $>200$ faculty members at 80 institutions worldwide. (More information about this method, particularly targeted to physics instruction, can be found in the recent book, Just-In-Time Teaching: Blending Active Learning with Web Technology [Novak et. al 1999].)

The essence of JiTT is the feedback loop between the Web and the classroom (Figure 1). Faculty use the Internet to post course materials and Web-based Warm Up assignments before class, and students use materials on the Web to prepare for each class. The faculty member in turn uses student responses to create an interactive classroom environment that emphasizes active learning and cooperative problem solving and decreases the use of traditional lecture. Further exploration of selected topics occurs after class in the form of "What is (Biology) Good For?" activities that highlight the relevance of course material to the student's lives. JiTT is particularly useful in large enrollment courses, for commuting or part-time students, and in any case in which a student's first allegiance is not necessarily to the course, but may be competing with the student's existing job, family, and personal responsibilities (Novak et. al 1999).

The purpose of this paper is fourfold: (1) To relate the use of JiTT to what is known about effective teaching and learning in science; (2) to describe how JiTT is currently used in biology; (3) to describe the effect of JiTT on student success and learning; and (4) to suggest strategies that faculty can use to implement JiTT in their own classrooms.

\section{OVERVIEW: WHAT DOES THE RESEARCH LITERATURE SAY ABOUT HOW STUDENTS LEARN SCIENCE?}

A review of the literature on how students learn science reveals at least three major themes: (1) Learning requires active practice. Extensive research in education has confirmed that deep conceptual learning requires interactive engagement, recently reviewed in How People Learn (National Research Council (NRC), 2000). For example, Hake (1998) compared >6,000 students from 62 different introductory physics courses and concluded that students who used active learning or interactive engagement methods outperformed students in traditional 


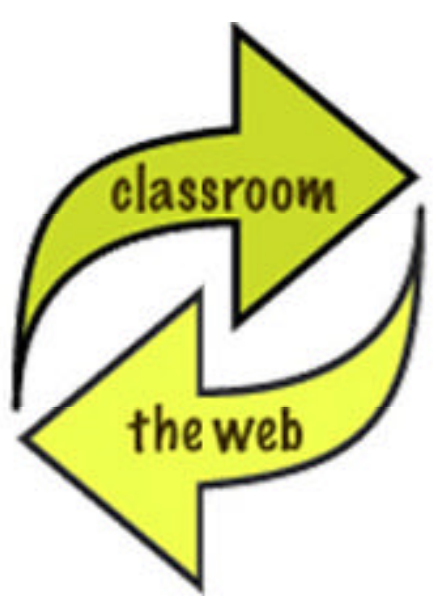

Figure 1. JiTT feedback loop.

classes. Similar results were seen by faculty teaching general chemistry and biology courses (Paulson 1999, Udovic 2002). Many recent reviews targeted to college faculty recommend active learning strategies to increase student success in college; including Astin's What Matters in College? Four Critical Years Revisited (1983), Chickering and Gamson's Seven Principles for Good Practice in Undergraduate Education (1987), NSF's Shaping the Future: New Expectations for Undergraduate Education in Science, Mathematics, Engineering, and Technology (1996) and NSTA's recent Learning Science and the Science of Learning (Bybee, 2002). (2) Learning is actively constructed from prior knowledge. Research in science education has also made us aware that, in order to learn, students must actively construct new knowledge from prior knowledge:

Current research on learning indicates that all new learning depends on the learner's prior knowledge and current state of understanding. If students' initial understanding is not engaged, they may fail to grasp the new concepts they are taught, or ...they may revert to their preconceptions outside of the classroom. (NRC 2000)

This theory of learning, termed 'constructivism,' was developed by Piaget and others and is well-supported in the research literature, as recently reviewed (NRC, 2000; Bybee, 2002). Prior knowledge is defined as a combination of a learner's preexisting attitudes, experiences, and knowledge (Kujawa and Huske, 1995). Many times, prior knowledge includes misconceptions, defined as intuitive but incorrect interpretations or misunderstandings of an idea, concept, or process (Fisher et al., 1986; Rochelle, 1995). Constructivism emphasizes that new concepts cannot be learned if alternate models already exist in a student's mind, and finds that new concepts are best learned when teachers uncover and address the prior knowledge and misconceptions that their students bring to class with them. (NRC 2000, Committee on Undergraduate Science Education 1997).

Learning requires prompt feedback: A large body of research has shown that learning proceeds primarily from prior knowledge, as described above, but also isbest achieved when students are provided opportunities for formative assessmentfeedback on their prior knowledge so that they can adjust or clarify their thinking (AAAS 1989, NRC 2000). However, in Learning Science and the Science of Learning (2002), Mestre and Cocking state that:
Largely missing from science classrooms, particularly large lecture classes, is formative assessment, which is intended to provide feedback during learning exercises so that students can have an opportunity to revise and improve their thinking and instructors can tailor instruction appropriately.

Feedback is most helpful to student learning when students have time to reflect on the feedback and make adjustments in their thinking to improve or clarify their understanding of subject material. Formative assessment gives students an opportunity for practice with concepts in preparation for a graded examination (summative assessment), when they will be asked to show what they have learned at the end of a set of course materials.

\section{JiTT Combines Research-based Learning Strategies}

A fundamental advantage of JiTT is that it provides a simple and straightforward way to have students and faculty participate in all of these learning strategies. The use of JiTT Web technology is simply one way to achieve these recommendations to promote the development of critical thinking, active learning and cooperative learning skills, and give quick and specific feedback to students. In addition, JiTT incorporates other recommendations for effective teaching and learning, by encouraging frequent, short study sessions when not in class, increasing the amount of contact between faculty and students, encouraging classroom attendance and participation and connecting the course content to the real world (relevance). (Chickering and Gamson 1987, National Research Council, 1996).

\section{HOW JiTT IS USED IN TWO CLASSROOMS: CONTEMPORARY BIOLOGY N100 AND BIOTECHNOLOGY 540}

At IUPUI, one of us (K.A.M.) has been using JiTT in biology classes since 1999. Contemporary Biology, N100, is a large-enrollment (>200 students), lecture hall course for nonscience majors who use the course as part of their general science requirement for graduation (http://www.biology.iupui.edu biocourses/ N100/). Biotechnology 540 has an enrollment maximum of 45 students, and is taken by advanced undergraduate biology majors and graduate students (http://www.biology.iupui.edu/ biocourses Biol540/). Both courses meet twice a week for $75 \mathrm{~min}$ each, and neither class has a lab associated with it. Both of these courses had been taught as traditionally lecture-based classes, but over the course of 3 yr have gradually incorporated features of JiTT. More than 1,000 biology students at IUPUI have been taught using JiTT.

While we will show here the way JiTT is used in Biology at IUPUI, we stress that faculty can tailor any of the following aspects of JiTT to best meet their own course needs. In fact, the way JiTT is actually implemented in Biology as described here is somewhat different from the way JiTT was originally described (Novak et al., 1999). The most important goal of JiTT is for faculty to help engage the students in the course content, and to help students achieve mastery of the subject through active learning, constructivism, and prompt feedback, using the technology as a lever to achieve these goals, and not as an end in itself (Chickering and Ehrmann 1996).

There are four common features of both Contemporary Biology and Biotechnology. The first is to use the Web to create a Dynamic Syllabus. The syllabus is on-line and updated weekly 
throughout the semester. New Web material is posted each Friday, at which point students can access the coming week's lecture outlines and Web assignments. As the cycle repeats itself throughout the semester, the students see the syllabus evolve as new links to course material and assignments are added. Figure 2 shows the home page and syllabus for Contemporary Biology, with icons linking the syllabus to the various course components, such as Lecture Notes, Warm Ups, and "What is Biology Good For?"

A second feature is the use of Web-based "Warm Up" assignments. Warm Up assignments prompt the students to think about the upcoming lesson and answer a few simple questions prior to class. One weekly Warm Up is posted each Friday and is due any time in the following week up to $3 \mathrm{~h}$ before class time the following Wednesday. Students read the text as well as look at the Web links to lecture outlines for the upcoming week before answering the Warm Up, with the actual Warm Up assignment taking about 15-20 min to complete. Figure 3 shows how a Warm Up exercise looks to students. Students complete Warm Up assignments at their own pace, and use a "Submit" button to transmit their answers automatically into a CGI-bin (Common Gateway Interface program; a standard Web page tool that collects responses from a form and stores the information in an HTML file, or bin) that can be accessed by faculty at any time.

The third feature of both Contemporary Biology and Biotechnology is an Interactive Classroom session. Typically, a modified lecture-discussion is done for the first $3 \mathrm{rd}$ of the class, incorporating student Warm Up responses as described in the next section, followed by a Cooperative Learning exercise, consisting of collaborative group work and discussion. This is followed by a second lecture discussion in the last third of the class.

A final feature that is used in Contemporary Biology only are optional "What is Biology Good For?" assignments, short essay that highlights the relevance of biology in everyday life. These extra credit assignments involve a small amount of internet research and are due the Friday following that week's classes.

\section{WARM UP ASSIGNMENTS: THE STARTING POINT IN THE JiTT FEEDBACK LOOP}

Warm Up exercises are used in a JiTT classroom in three ways: (1) to identify student beliefs, misconceptions and prior knowledge; (2) to synchronize the student responses with classroom instruction; and (3) provide classroom time to confront miscon-

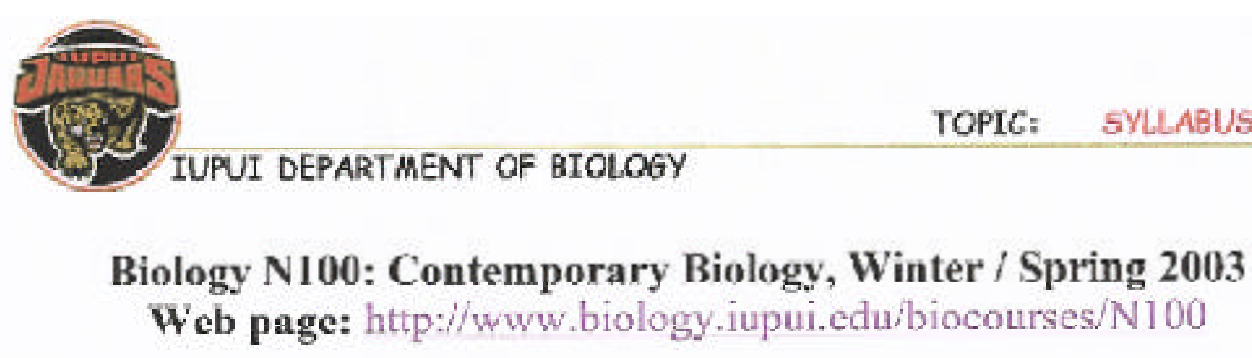

\begin{tabular}{|l|l|}
\hline Winter - Spring 2003 & Sections A433, A434, and \\
Mon. \& Weds. 1:00 AM - 2:15 PM & R903 \\
Professor: Dr. Kathleen A. Marrs & LE 101 \\
E-mail: kmarr@iupui.edu & Phone: 278-4551 \\
\hline
\end{tabular}

Support for the development of this course was provided by the National Science Foundation, Division of Undergraduate Education (NSF-DUE Award 9981111), to the WebScience Project at Indiana University-Purdue University at Indianapolis.

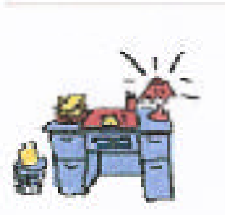

Lecture Notes
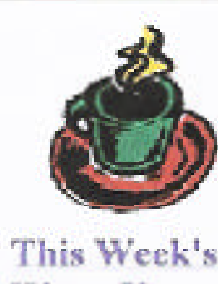

Warmup

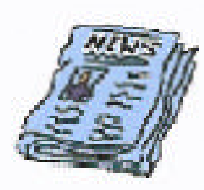

Biology in the News
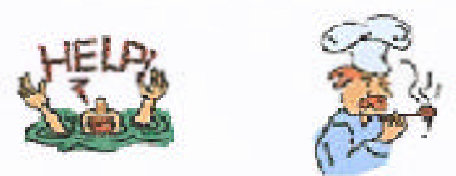

II lp

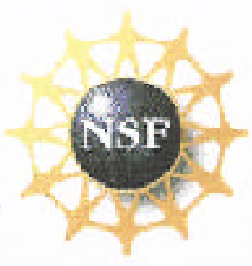

Figure 2. Home page of Contemporary Biology,N100 atIUPUI(http:/Wwww.biology.iupui.edu/biocourses N100 $)$. From this main page, students have access to the class lecture outlines (desk icon), the weekly Warm Up exercise (coffee cup icon), Biology in the News articles (newspaper icon), a page of helpful tips useful for preparing for exams (help icon) and the weekly “What is Biology Good For?" exercises (Chef icon). The home page also contains the general course syllabus, including a grading scale and descriptions of course policies and procedures (not shown). 


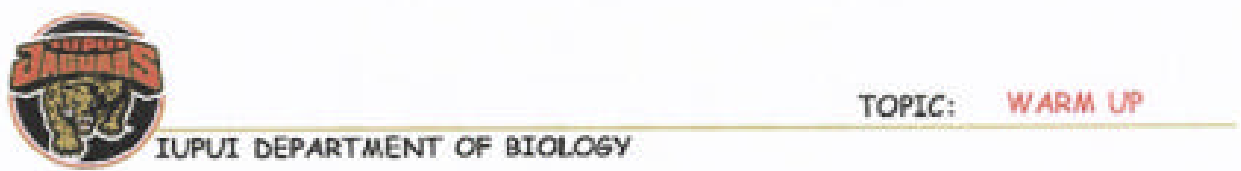

Warm Up I is due Wednesday, January 22, 2003 at 9:30 am.

Please type the last 4 digits of your Student ID Number: 9876

(Important!)

Please type your LAST name, and FIRST initial or first name; Guess Who!

Please type in a 'nickname':

(In case your answer is used in class)

\begin{abstract}
The following three questions refer to material you were to read in preparation for class. These questions require you to write a three or four sentenee response. It is OK to answer 'I don't know' - but STATE WHY you are confused! (Don't just say 'I don't know' - you probably DO!) Each Warm Up worth 3 points if answered on time and must be submitted via the web.
\end{abstract}

QUESTION 1: What is the difference between a theory and a belief? You may want to look these terms up before answering. Be as specific as you can, and give an example of each.

QUESTION 2: What characteristic determines whether organisms belong to the same species? Why are, for instance, are Rottweilers, bulldogs, and poodles - phenotypically (ie physical appearance) very different - considered to be members of the same species - dogs? Why are all humans, despite our numerous phenotypic differences, considered to be one species?

You may change your mind as often as you wish. When you are satisfied with your responses click the SUBMIT button. You will receive a "THANK YOU" page as a confirmation that your response has been sent to me.

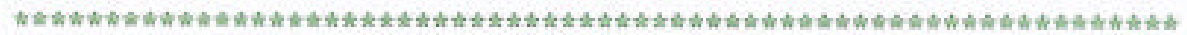

Figure 3. Lay out of a typical Warm Up assignment in Contemporary Biology. Students must enter their last name and first initial, the last four digits of their student identification umber, and a nickname for purposes of anonymity if their response is shown in class. A "Submit" button at the bottom of the exercise transmits student answers to faculty. Students receive a confirmation page once their Warm Up has been successfully submitted. Students receive 3 points for answering each Warm Up on time as it appears at the top of the Web page. 
ceptions. In doing so, we incorporate students' prior knowledge as a foundation on which to construct further knowledge of the subject matter.

\section{How Are Warm Up Questions Written?}

A Warm Up question usually presents a situation that students are likely to be somewhat familiar with and requires students to speculate or develop a hypothesis before forming the answer. Students typically reveal, through writing the answer to the Warm Up question, ideas (and misconceptions) based on both their prior knowledge of the subject—from high school or earlier classroom experiences, from other college courses, or from the media - with new information gathered from reading the textbook or lecture notes. Since Warm Up exercises are primarily intended to uncover student prior knowledge, we typically do not question students on direct factual information found in the textbook. Instead, we ask questions that start with open-ended prompts such as:

"What is the difference between...?"

"Why do you think...?"

"Estimate how many...."

"What happens if...?"

"What determines...?"

"In your own words, explain..."

In some cases, Warm Up questions can be designed to target concepts that are known from the research literature to be associated with specific misconceptions by students. For instance, many undergraduate students have significant misconceptions about concepts such as evolution and natural selection (Bishop and Anderson, 1990; Hensen and Finley, 1996; Lord and Marino, 1993; Lawson and Thompson, 1988), photosynthesis and respiration (Haslam and Treagust, 1987; Hazel and Prosser, 1994), osmosis and diffusion (Jensen et al., 1996; Odom and Barrow, 1995; Westbrook and Marek, 1991), and understanding the biochemical basis of "dominant versus recessive" traits (Heim, 1991; Longden, 1982). For concepts such as these, significant misconceptions can be anticipated in student responses to Warm Up questions and even categorized into fairly predictable responses.

In other cases, an instructor might want to probe for student prior knowledge on concepts that do not have a strong base of information about existing misconceptions. In such a case, we have found it useful to write Warm Up questions based on categories described in the classic article by Arons (1979) that describes the reasoning capacities that faculty expect of college students. Figure 4 shows a sampling of Warm Up questions that have been used in both Contemporary Biology and Biotechnology that fall into one of the categories described by Arons (1979).

For example, a Warm Up question might probe for the ability of a student to understand new terms and definitions (Figure 4, question 1 and 9), explain or discuss the meaning of a particular bit of jargon (Figure 4, question 2 and 12), or show students ' thinking processes when dealing with a difficult concept (Figure 4, question 3,9, and 10). Other Warm Up questions might probe for whether a student can draw inferences from data (Figure 4, question 4), translate words into written symbols or written symbols into words (Figure 4, question 5), make connections between the subject and their own experiences (Figure 4, questions 6 and 7), or discuss the ethical implications of biology (Figure 4, questions 8 and 11). Student responses to these questions include not only some misconceptions that might be predicted from the research literature, but will also reveal prior knowledge and other misconceptions that might never have occurred to the faculty member to address without seeing the responses of his or her own students. It is often fascinating to read through student responses and see the wide range of thought processes, examples, analogies, mis-information and logical thinking that students use to answer the questions!

In both biology classes at IUPUI, Warm Up responses are due $3 \mathrm{~h}$ before class time. (Any time period before class time can be chosen that is convenient for the faculty member and the students answering the Warm Ups.) Having an assignment due before class time has an added benefit - it compels the student to do the readings and look at the chapter material so that students come to class prepared, increasing their participation in class discussions and cooperative learning exercises.

Full points ( 3 points per Warm up assignment) are given to all students who respond on time-Warm Up responses are not graded initially as right or wrong since the material has not yet been discussed in class. The answers do not have to be complete, or even correct. In fact, partially correct responses are the most useful in starting classroom discussion, as described in the next section.

If a faculty member prefers to assign a grade to the students ' warm up responses, we have developed a way to score student responses to Warm Up responses, based on a scale from 1 to 4 , with 1 representing "no formal understanding" of the question to 4 representing "complete formal understanding" of the subject, based on a rubric developed by de Caprariis et al (2001). For more details on scoring Warm Ups, including actual student responses to different Warm Up questions, see the recent paper by Marrs et al (2003), the archive of Warm Up exercises in biology, including selected student responses at, or the Warm Up scoring rubric at http:/wwww.biology.iupui.edu/biocourses/ N100/warmupscoringrubric.html.

\section{WARM UP RESPONSES: SYNCHRONIZING PRIOR KNOWLEDGE WITH CLASSROOM DISCUSSION}

Faculty using JiTT typically set aside an hour or sobefore class to read through student responses. While reading student Warm Up responses, it is usually evident that the students are clear about some points but may have serious misconceptions about other questions.

Once we identify a few points that need to be further clarified in that day's class, based on reading a sample of student responses, we determine where to adjust the upcoming classroom lesson in response to the student submissions "Just in Time," and decide how much time to devote to a concept that was to be discussed that day. Should the majority of the class appear to be confused on a particular Warm Up question, more time can be planned to clarify this concept in class. Should the majority of the class appear to understand a concept, more time can be spent in class discussing other concepts.

Just before class time, we select two to four Warm Up responses for each question that can be used as a starting point for addressing that day's content, and copy and paste these responses into a page of comments. This page can be uploaded immediately to the course Web page, or a transparency can be made and shown in class. 


\section{Figure 4: A sampling of Warm Up questions used in Contemporary Biology (1-8) and} Biotechnology (9-12).

1. What is the difference between a theory and a belief? You may want to look these terms up before answering. Be as specific as you can, and give an example of each.

2. What characteristic determines whether organisms belong to the same species? Why are, for instance, are Rottweilers, bulldogs, and poodles - phenotypically very different considered to be members of the same species - dogs? Why are all humans, despite our numerous phenotypic differences, considered to be one species?

3. How do you think cells become specialized for their function? For instance, we all started our life as one single fertilized egg cell, or zygote, but within weeks of conception, we had liver cells, heart cells, brain cells, and muscle cells that were grouped into functioning organs. How does one cell give rise to many cells with many different functions??

4. A protein called "p53" normally functions to find damaged DNA in the nucleus. p53 prevents cells from going through mitosis until the DNA damage can be repaired. However, smoking cigarettes frequently causes mutations in the p53 gene in lung cells. How do think this might play a factor in the development of lung cancer?

5. One of my favorite quotes about biology refers to photosynthesis: 'Life is woven out of air by light". Look at the chemical equation for photosynthesis is this week's readings. In your own words, explain what you think the author of this quote meant based on the chemical reaction for photosynthesis.

6. Why do you think chemotherapy drugs, which are given to fight cancer, cause a person's hair to fall out?

7 Which gender is doing more meiosis RIGHT NOW - the males or the females? (Or do you think men and women undergo meiosis at pretty much equal rates?) What type of cell is the end product of meiosis in men? What type of cell is the end product of meiosis in women?

8. Is there a flaw in thinking that if we were ever to clone a person, like Einstein, a brilliant physicist, we would end up with another brilliant physicist?

9. How does an organism's physical appearance relate to Survival of the Fittest? How does the environment influence the survival of an organism?

10. Humulin, a drug made by Eli Lilly, is the human insulin protein made by bacteria. How can a bacteria make a human protein?

11. Where do Human Embryonic Stem Cells (hES cells) come from? What are some of the ethical implications of using hES cells for medical research?

12. If the genome is all the DNA in the nucleus of one cell, what is a proteome? Could there ever be a Human Proteome Project?

For sample student responses to these Warm Up questions, see

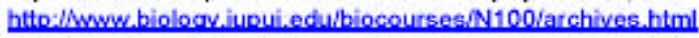

Figure 4. Selected Warm Up questions used in Contemporary Biology (1-8) and Biotechnology (9-12). For sample student responses to all Warm Up exercises in Contemporary Biology, see the Contemporary Biology Resource Page at http://www.biology.iupui.edu/biocourses/N100/ archives.html.

\section{How To "Spin" Student Warm Up Responses in Class}

An important feature of JiTT is that students actively participate in a class that is based on their prior knowledge, while still including all the content the faculty member was planning for that day's discussion. Student responses to the Warm Up questions are shown and discussed where appropriate in the lecture or discussion. There are many ways the student excerpts can be used in class, as shown in Figure 5. Incomplete answers are often the best for stimulating an active classroom discus- sion. Students can be asked, as a class, to extend answers beyond what is shown to make the student responses more complete, to expand the answers to a new situation, or to compare two answers to the same question that differ significantly. Student Warm Up responses are thus used to provide quick and specific feedback to students, by using their own responses as a springboard to develop subject material presented to class. Thus, JiTT provides a simple way to provide continuous formative assessment to students, giving students time to review their thought processes, and to revise their thinking if needed. 
Students report that they benefit from going over the sample Warm Up responses in class, and are usually pleased to see their answer presented to the class, identified by an anonymous (and sometimes humorous), nickname, even if the answer presented is partially incorrect. In questioning three semesters of students, $87 \%$ of students in N100 rated the class discussions of Warm Up responses "very useful to learning the fine points " of a concept $(n=485)$. It should again be stressed that the time spent on Warm Up responses in a JiTT classroom does not result in less course content or "coverage" of topics; in fact, students spend more time reading, writing, and thinking about a topic in a JiTT classroom due to the necessity of completing assignments out of class.

\section{INTERACTIVE LECTURE: COOPERATIVE LEARNING AND DISCUSSION}

Students in a JiTT classroom actively work on their knowledge of specific concepts during class by not only discussing Warm Up responses, but also working on solving problems in a group setting. In Contemporary Biology, understanding is further reinforced by in-class Cooperative Learning exercises that deal directly with the concepts discussed in class. These exercises are chosen so that they give students hands-on experience with specific concepts: for example, transcription and translation using the codon chart, genetics problems, or graphing exercises to show exponential population growth or antibiotic resistance. In some cases, Cooperative Learning exercises are chosen specifically to 'tie in ' with a particular Warm Up question and provide a 'two-pronged attack' to give additional attention to particularly difficult concepts (Marrs 2003).

Many of these Cooperative Learning exercises come from the book Cooperative Learning: Making Connections in General Biology (Bres and Weisshaar, 2000). This soft cover book contains about 100 hands-on, cooperative learning activities for biology students (majors or nonmajors) that are easily done in the classroom, typically in 10-15 min or less. The book includes activity worksheets correlated to the content of many standard general biology textbooks, with sections covering cell structure and function, mitosis and meiosis, evolution, genetics, and more. For faculty who may be uncertain of how cooperative learning might be implemented in their classrooms, particularly in a large lecture hall classroom, an instructor's manual is available which not only includes answers to the cooperative learning activities but also includes tips for incorporating aspects of cooperative learning and group work into a course.

In Contemporary Biology at IUPUI, informal groups of two to four students work together for 10-15 min on these cooperative activities and are given time to ask questions and discuss their answers with other groups. In this way, students who continue to have difficulty with a concept can get clarification while class is still in session. Since Contemporary Biology is held in a less-than-ideal setting for group work (fixed, auditorium-style seating), students are not assigned into groups, but work informally with people who are next to them, or in rows in front of behind them. While students are sometimes hesitant at the beginning of the semester to work with other students, they quickly come to enjoy the break in lecture and welcome the chance practice working with concepts we are discussing in class. Over $94 \%$ of students in one semester of N100 $(n=184)$ reported that the cooperative learning exercises were "highly useful" or "very useful" in promoting understanding of the

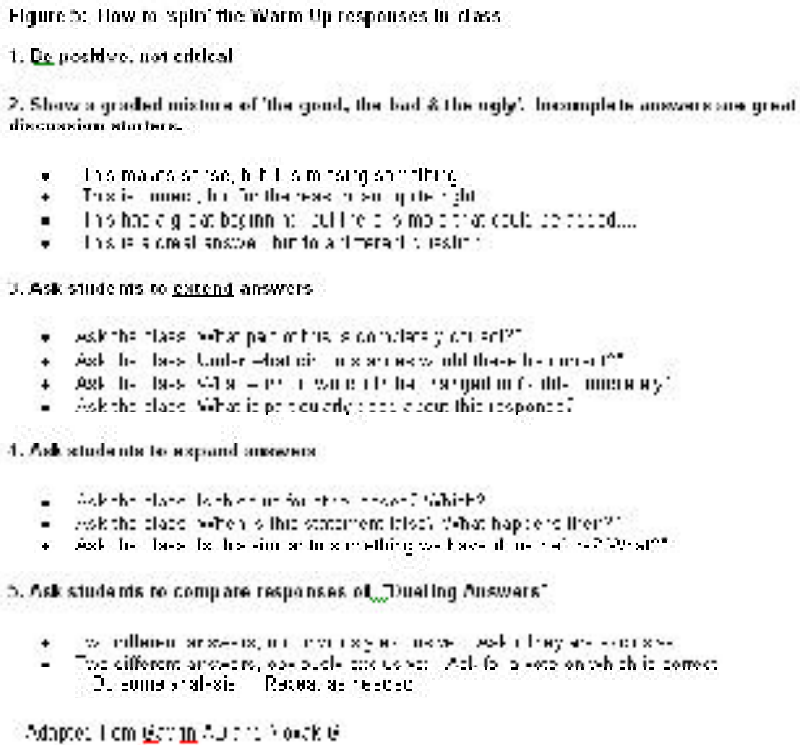

Figure 5. Examples of prompts that can be used to "spin" or discuss student Warm Up responses in class.

concepts discussed in class, as scored on a Lickert Scale. We have found two other benefits of the cooperative learning exercises that are not directly related to facilitating understanding of course content. One is that the cooperative learning exercises foster student-to-student interaction, and many times result in the formation of study groups outside of class, an important factor for student success that is often difficult to establish on an urban campus. A second is that, if graded, the cooperative learning exercises strongly promote classroom attendance. In Contemporary Biology, two Cooperative Learning exercises are done per week (one per class). Each exercise that is graded is worth 3 points each, for a total of only 45 points for the semester ( $<8 \%$ of the total points in the class). However, only one of the two exercises done per week is graded; the other is discussed and corrected in class but is not turned in and does not contribute to the students' grade. Students do not necessarily know which of the two weekly exercises will be graded, and as a result typically attend both classes per week. As a result, Contemporary Biology has a very high rate of classroom attendance. In a class of usually more than 200 students, more than $85 \%$ of the class is in attendance - with an average of 170 students per class session, an almost doubling of the numbers of students attending class before cooperative learning exercises were implemented.

It is fairly straightforward to tailor Cooperative Learning exercises to any biology class by looking for simple activities in lab manuals, student study guides, or on the internet for activities that might be done to make a lecture class more interactive. The benefits of cooperative learning in teaching cell biology, and excellent tips for incorporating cooperative learning into biology classes has been recently reviewed in Cell Biology Education by Tanner et al (2003). Cooperative learning has been strongly recommended by the AAAS as part of good practice in teaching science. As recommended in Science for All Americans (AAAS, 1989) science should be taught in a way that is 
consistent with the way that science is done-by inquiry and collaboration, working with real data.

\section{"WHAT IS BIOLOGY GOOD FOR?" EXERCISES: EXTENDING THE CLASSROOM EXPERIENCE}

Biology is undoubtedly the most rapidly advancing branch of science today. Cell biology alone has seen an impressive increase recently in the knowledge about signal transduction, protein sorting, regulation of gene expression, cell division, and molecular genetics. Obviously, not all of these topics can become part of the curriculum. However, faculty may feel that a certain topic could really be beneficial or interesting to those students motivated enough to want to go a little more in depth than the curriculum permits.

To introduce these extra-curricular topics and enhance student motivation (Gavrin and Novak 1999), JiTT uses a final optional assignment, called "What is (Biology) Good For?" (each discipline, of course, having its own version of the "Good For" essay). In biology at IUPUI, these essays are only used in N100, the course for non-science majors, Figure 6 shows a listing of Good Fors used in Contemporary Biology. The Good For essays provide a reasonable introduction to a subject, typically in $\sim 1,000$ words and a few figures, followed by 3 research questions for which students may earn 3 points of "extra credit," for a total of 30 points for the semester (out of 600 points total). This small amount of credit, however, is enough to achieve considerable participation. In a given week, $>75 \%$ of the students of the students submit responses to the optional Good For essays, which are due the Friday after that week's classes.

The Good Fors are written to provide a clear sense of the excitement of modern biology, by directly linking material in the text to a practical application of biology upon which lives may depend. The research questions at the end of the essays require students to do a bit of guided internet research using links included throughout the body of the essay or in a set of "further reading" links at the end. The goal is to activate the students' interest and the idea that biology occupies a central position in their lives. Ideally, students begin to tune into news stories about biology in their everyday lives. The "Good For" essays have the additional effect of promoting science literacy, requiring students to practice their writing skills, and gaining experience using the Web as a resource (Gavrin and Novak 1999). While we have tended to write the Good For essays ourselves for our classes, it is not necessary that a faculty member spend time developing and writing these essays themselves. Instead, numerous Web sites that write up daily science news or summarize scientific processes can be used as "Good For" assignments. Students can simply be directed by a link to a story of interest, and then answer questions provided by the faculty member. Some Web sites are to consider, particularly for science majors, are Nature Science Updates (http://nature.com/nsu) or Scientific American (http://www.sciam.com), among many others.

Often, a controversy or an interesting history behind the subject of a Good For is intriguing to many students, and a topic of before-class conversation in the classroom that week. One of the most popular "What is Biology Good For?" essays concerns the use of the Biotechnology drug Epogen, a life-saving drug that has revolutionized life for patients suffering from kidney disease or the effects of chemotherapy. In itself, the development of this drug and its effect on patients'lives is an interesting story, but additional controversies about "Epo" blood dop-

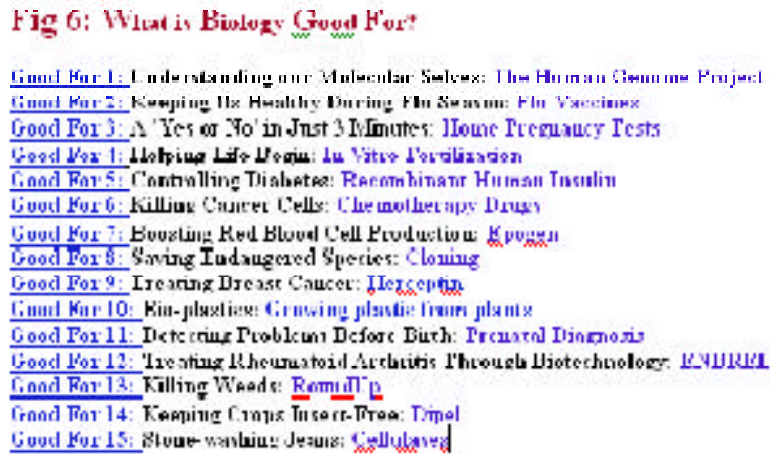

Figure 6. Selected "What is Biology Good For?" exercises used in Contemporary Biology.

ing by athletes and the reluctance of Medicare to subsidize the complete cost of this drug makes for many interesting Web responses and student conversations. Figure 7 shows a portion of this Good For assignment.

Student reaction to the Good For essays is extremely favorable. When asked to rate the Good For assignments, over $90 \%$ of the students questioned reported that the Good Fors made them understand the relevance of science to their lives $(n=170)$. Helping students, particularly nonscience majors, to understand the relevance recommended in the as a basis for developing scientific understanding and scientific literacy (National Research Council, 1996).

\section{ASSESSMENT: EFFECT OF JiTT ON STUDENT LEARNING AND STUDENT SUCCESS}

\section{JiTT Increases Classroom Interactivity}

One of the "Seven Principles for Good Practice in Undergraduate Education" (Chickering and Gamson, 1987) is to encourage interaction between students and faculty in and out of classes. A JiTT classroom has high levels of interaction between students and faculty via Warm Up exercises and cooperative learning exercises. Based on reports from trained classroom observers (graduate students in Psychology) as well as peer (faculty) evaluators who were not using JiTT, a JiTT classroom has substantially more student-student interaction (students involved in group work, students discussing Warm Up responses as a class), and more student-faculty interaction (students asking questions or making comments to faculty during class discussions of Warm Ups or Cooperative Learning assignments) than does a non-JiTT classroom, as measured by observation of student questions and comments to faculty, faculty questions to students, and student interaction during group work.

\section{JiTT Provides Ongoing Formative Assessment to Students}

JiTT provides an excellent way to give students feedback on their understanding before taking a test for a grade. By examining students 'Warm Up responses as "works in progress" and providing quick and specific feedback during class, and allowing for in-class cooperative active learning, students are given many opportunities to explore their own thought processes 
about a particular concept, and revise their thinking, if necessary. In questioning three semesters of students, $87 \%$ of students in N100 rated the class discussions of Warm Up responses "very useful to learning the fine points" of a concept $(n=485)$, and $>94 \%$ of students in one semester of N100 $(n=184)$ reported that the cooperative learning exercises were "highlyuseful" or "very useful" in promoting understanding of the concepts discussed in class, as scored on a Lickert Scale.

\section{JITT Increases Student Success as Measured by Course Retention Rates}

Introductory courses in biology, as well as some upper level courses that are more conceptual or theoretical in nature (for example, genetics), commonly have large numbers of students who do not perform well in class, and who either withdraw from the class $(W)$, or receive either a D or an $F$ for their semester grade. A common goal for faculty and for a university is to successfully retain more students without changing or simplifying the course content, reducing the number of students who leave the course with a D, F, or W. In physics, use of JiTT has resulted in a $33 \%$ DFW rate being lowered to $19 \%$ using JiTT, meaning that $81 \%$ of the students will complete the course with a grade of A, B, or C. Since implementing JiTT in contemporary biology, the DFW rate has decreased from $27 \%$ to $20 \%$; meaning that $80 \%$ of the students taking N100 will now complete the course with a grade of $\mathrm{A}, \mathrm{B}$, or $\mathrm{C}$.

\section{JiTT Improves Class Preparation}

To make the best use of in-class time, many instructors would agree that it is important for students to come to class prepared. In a JiTT classroom-and indeed in any classroom that is not taught using a traditional lecture format-the value of the class depends on the quality of the participation. When taking a JiTT course, students are told that we, their professors, will come into class expecting that they will have read the notes and the pages in the book to become familiar with new terms and concepts for the day. To determine whether students changed or improved their likelihood of class preparation as a result of using JiTT, we asked students three questions to determine whether they were preparing for class (Table 1 ). We asked students three questions: (1) Do you read the Web notesbeforeclass? (2) Do you do the readings from the text before class? (3) Do you do read the textbook or the class notes (if provided) before your other classes? The results in Table 1 show that only $\sim 50 \%$ of the students who were scoring in the an $\mathrm{A}, \mathrm{B}$, or $\mathrm{C}$ range after the third exam in Contemporary Biology self-reported that they read the textbook and notes before their non-JiTT classed, whereas $\sim 75 \%$ of students who were scoring in the an $A, B$, or a $C$ range reported preparing for class in Contemporary Biology. Students who were not doing well in the class, scoring in the D or $\mathrm{F}$ range after the third exam of the semester, also self-reported that they were not preparing for class. It is likely that this lack of preparation, as well as other factors relating to their personal circumstances, was negatively affecting their course performance.

\section{JiTT Improves Student Study Habits}

Developing good study habits is one of the most effective ways to succeed in college. Research has shown that students learn more efficiently and retain information longer when they study regularly, and retain much less information from a single, intensive study session (NRC, 2000; Holloway, 2000; Bybee, 2002; Kirkland, 1979; Hoover, 2002). 'Cramming' —a single, intensive study session that saturates the short-term memory with information before an exam - is a technique most college students will use at times, but unfortunately, it is not an efficient way to acquire or retain knowledge (Holloway, 2000; Bybee, 2002; Kirkland, 1979; Hoover, 2002). We wanted to determine whether Warm Ups made a significant difference in student study skills, making it easier for students to study in shorter, more frequent study sessions. We asked students to report whether they crammed for exams in Contemporary Biology versus their other, non-JiTT classes. As shown in Table 2, 40\% of A students, $65 \%$ of B and C students and $70 \%$ of D and F students self report that they cram for exams in their non-JiTT classes. However, only $16 \%$ of those same A students felt the need to cram for N100. Students receiving a B or a C also showed an improvement in their study skills (with $<31 \%$ and $44 \%$, respectively, still feeling like they needed to cram). About $70 \%$ of students who were receiving poor grades in the class (D or F) still felt the need to cram whether they were in a JiTT class or not. The lack of effect on these students' study skills, combined with their lack of preparation for the class as described above, indicates that many of these students most likely lacked either the study habits, the motivation, or the time needed to succeed in a college classroom.

\section{But Are They Learning? JiTT Increases Cognitive Gains in Biology}

In physics, students from JiTT classrooms showed significant and measurable gains in achievement on a standardized test in Physics, the Force Concept Inventory (Hestenes et al., 1992). A similar tool, the Biology Concept Inventory, is currently under development (Klymkowsky 2003), but is not yet in use. To measure the effect of JiTT on cognitive gains in biology, we have used the results from a 20-question preclass and postclass test, calculating the average normalized gain as described (Hake, 2002; reviewed in Dancy and Beichner, 2002). In doing this analysis within individual N100 classes, we found that students tended to show an average normalized gain of $\sim 15 \%$ on test questions about concepts that were discussed in class, but not necessarily reinforced by any additional class activities, and showed an average normalized gain of $\sim 21 \%$ on test questions that were reinforced by back of the book homework problems. However, students tended to show an average normalized gain of $\sim 52 \%$ on test questions that were reinforced by either Warm Up questions or Cooperative Learning activities, and showed an average normalized gain of $\sim 60 \%$ on test questions reinforced by both Warm Up questions or Cooperative Learning activities (Marrs 2003).

Students prefer JiTT to traditional lecture classes, based on course attitude surveys, anonymous end-of-course evaluations, and student focus groups:

The Web page was great. I've never had a class run from the Web before and it was really neat. All of the different categories (Warm up, Good Fors, notes) were really great and made the class fun and interesting and different.

I enjoy reading the "What is Biology Good For" assignments, I learn a lot of details that I probably would not have known. The Good Fors help me to connect biology to the real world and it is very incredible. I have not yet had another class that helped connect the subject with the real world. 


\author{
What is Biology (Good For? \\ Boosting Red Blood Cell Production: Epogen
}

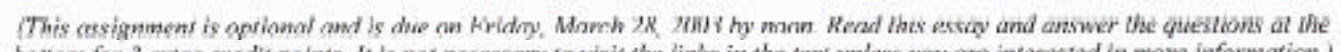
bottom for 3 extra credli polnis. It is not necessary to visis the links in the nexl unlexs you are interested in more information.)

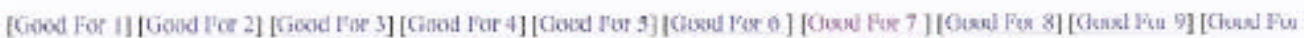
10] [Good For 11] [Goud For 12] [Good For 13] [Good For 14] [Good For 15]
\end{abstract}

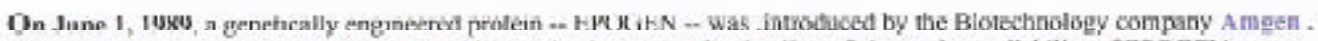
providing patients with kidney failure the ability to lead more productive lives. Prior to the availability of EPOGEN, many individuals receiving dialysis treatments were affected by debilitating anemia (low red blood cell count) found in approximatcly $90 \% 4$ of all lidney dialysis potients.

Anemia: Many symptoms associated with kidney failure - despite excellent dialysis care - are frequently dos te anemia. This snemia is saused by insufficient production of erythrepoiefin. ? protein naturally produced in the functioning kidneys, which circulates through the bloodstream to the bone marrow, stimulating production of red blood cells (RBCs). Without adequate

crythropoictin, there arc too few RDCs to deliver oxygen to tixauca. Anemia developa, loaving dialysis patients tired, sometimes unable to work or perform even routine tasks. A person with anemia may feel tired and weak and may lack energy. Even mild exercise may bring on fatigue, difficulty io breathing and chest pain. Bicod transfusions ean be performed to relieve the anemiu, but they cun be puteutially

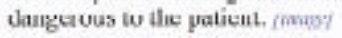

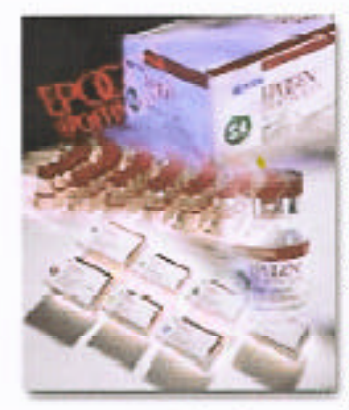

EPO on a regular basis.

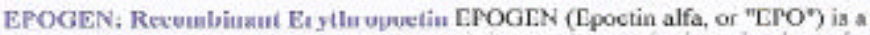
recombinant DNA version of the human erythropoetin protein that stimulates the production of RBCs. EPO is identical to natural erythropoetin, works in the same way, and has the same hèneficial effects as the eryntropoietin naturally prodiced by healthy kidneys. Erythropoetin is u faitly snall prosein of 163 anmine acids. Howeve. EFO, unlike Insulia, is a conplicated buman protein, too complicated to be msde correctly in bacteria. It must be made is small batches in animal tisue cuiture cells called Chincere Hamster Drary cells (CHO celle) Once tsolated and puritıed, however, EPU supplements the dealysis palientis supply of erythropoietin and provides the boost neoded to stimulate the production of anadequate supply of red blood cells.

Errects and Usage of RPO: Since its approval in 1989, EPU has elimimated the need for blood transfusions and helps correot anemia in dialysis patiento. Tonday, mosit dialysis patisnte receive EPO by injection as part of their treatment. More than $\mathbf{1 5 0 , 0 0 6}$ dialysis patients take

Studies have demonstrated that an mereased hematocrit (\%RBCs in blocd volume) resulting from Ero therapy has significant impact on the dialysis patieats' lives. The target hematocrit range for dialysis paticnts using EPO therapy is $30-$ $36 \%$. Ifealthy persons have a hematocrit range of $38-46 \%$. Studics bave showed no consistcnily obacrved side cffecta as a result of treatment with EPO other than mild hypertension and flu-like symptoms. EPO is an expensive dug, costing Medicare over $\$ 1$ billion a year and boasts annual sales of over \$4 billioa a year.

Figure 7. Portion of a "What is Biology Good For?" exercise on the biotechnology drug Epogen. Student read the essay, then complete three questions requiring internet research. A "Submit" button at the bottom of the exercise transmits student answers to faculty. Students receive a confirmation page once their Good For assignment has been successfully submitted. Students receive three extra credit points for correctly answering each Good For question.

I think that the Cooperative Learning exercises help me to learn the material. They are a mini review for me!! They definitely help break up the tedium of lecture. They are wonderful!! Plus I like the fact that they can kind of take attendance for those of us who show up to class everyday!

One of the best things about class in my opinion is that the information is usually so current. More than once a week I see things we have talked about. Often they are major news stories and it is a good feeling to be current to the advances in science and know what we have done is relevant to life stories.
I LOVE the Good Fors! I like the extra credit and it is great to see how biology is used in the real world. It is always frustrating when teachers can't answer the question "When am I ever going to use this?" Thanks for being so helpful!

\section{CONCLUSION: ADVANTAGES IN USING JiTT IN TEACHING AND LEARNING BIOLOGY}

JiTT is consistent with practices recommended for effective learning, including constructivism, active learning, and use of 


\begin{tabular}{lccc}
\hline \multicolumn{3}{l}{ Table 1. JiTT increases class preparation } \\
\hline Student & $\begin{array}{c}\text { Read web notes } \\
\text { beforeclass }\end{array}$ & $\begin{array}{c}\text { Read book } \\
\text { beforeclass }\end{array}$ & $\begin{array}{c}\text { Read book in } \\
\text { otherclasses }\end{array}$ \\
\hline A students & $78 \%$ & $65 \%$ & $53 \%$ \\
B students & $75 \%$ & $72 \%$ & $48 \%$ \\
C students & $63 \%$ & $61 \%$ & $51 \%$ \\
D students & $45 \%$ & $40 \%$ & $40 \%$ \\
F students & $46 \%$ & $42 \%$ & $42 \%$ \\
\hline
\end{tabular}

Students were asked: (Column 1) Do you read the web notes before class? (Column 2) Do you do the readings from the text before class? (Column 3) Do you do read the textbook or the class notes (if provided) before your other classes? Student responses were grouped depending on the course grade students were receiving $(\mathrm{A}-\mathrm{F})$ after taking the third of four exams. $n=162$.

formative assessment. Warm Up and cooperative learning exercises allow students to build new knowledge based on their prior knowledge and confront their misconceptions about difficult concepts. "What is Biology Good For?" exercises allow students to see the relevance of Biology to their everyday lives, as recommended in the National Science Education Standards (1996). By examining students " "work in progress" and providing feedback to students, JiTT is an excellent way for faculty to bring formative assessment in their classrooms, and by using informal group Cooperative Learning exercises, students learn science by inquiry and collaboration in a way that is consistent with the way that science is done, as recommended in Science for All Americans (Project 2061 AAAS, 1989) Finally, by requiring students to prepare ahead for class, and attend class regularly, JiTT promotes good study habits necessary for student success. In addition, students consistently score better on exam questions addressed by either Warm Up questions or Cooperative Learning exercises, indicating that use of JiTT results in a strong increase in cognitive gains (Marrs 2003).

Finally, JiTT is also consistent with many of the procedures and practices recommended for effective undergraduate teaching. Five of the "Seven Principles for Good Practice in Undergraduate Education" are directly addressed by JiTT: increased student-faculty contact, active learning techniques, prompt feedback, cooperation among students, and time on task, with the other two being indirect effects of JiTT (respecting diverse ways of learning, communicating high expectations).

\begin{tabular}{lcc}
\hline Table 2. JiTTimproves student study skills & \\
\hline Student & $\begin{array}{c}\text { Crammed in } \\
\text { Contemporary Biology }\end{array}$ & $\begin{array}{c}\text { Crammed in } \\
\text { other courses }\end{array}$ \\
\hline A students & $16 \%$ & $44 \%$ \\
B students & $34 \%$ & $63 \%$ \\
C students & $41 \%$ & $65 \%$ \\
D students & $64 \%$ & $71 \%$ \\
F students & $68 \%$ & $69 \%$ \\
\hline
\end{tabular}

Students were asked to report whether they crammed for exams in Contemporary Biology versus their other, non-JiTT classes. Cramming was defined as "saving virtually all studying for the day or night before or of the exam." Student responses were grouped depending on the course grade students were receiving $(\mathrm{A}-\mathrm{F})$ after taking the third of four exams. $n=426$.

\section{Getting Started with JiTT Is Simple}

Faculty interested in JiTT but unfamiliar with posting course materials to the Web can start slowly; by learning how to implement JiTT into a classroom in small pieces, faculty will become more comfortable with using the Web as a teaching tool in science. Very little technical knowledge of Web page construction is needed for faculty to implement all aspects in JiTT into a course, and in today's Web-savvy society, access to and familiarity with the Web is almost a given for college students.

Many universities have course management software like BlackBoard, WebCT, or Angel that provide an ideal format for JiTT, allowing faculty to not only post notes, announcements, or news, but also set up "Discussion Forums" that can be used as templates for Warm Up and Good For assignments. Course management software often has the advantage of automatically grading assignments that come as discussion forums, saving faculty from needing to manually grade Warm Ups or Good For assignments, and in some cases can keep a database of questions from which faculty can easily select or customize assignments (for example, see discussion by Ledder 2002). If course management software is unavailable, interested faculty can register at a new site (http://www.jittWeb.org). This site was developed at IUPUI for Indianapolis high school teachers who are using JiTT in their science classes, but is free to all users within the JiTT community. This site allows JiTT users to generate Warm Up forms to post on their home server, retrieve and grade student responses on-line, and import graded student responses into an Excel spreadsheet. Please contact author Kathy Marrs for more information about using jittWeb.org. For multiday workshops about JiTT, The National Science Foundation and Project Kaleidoscope (PKAL) offer summer workshops in Just in Time teaching. Feel free to contact either authors of this manuscript for more information.

\section{Is It Worth the Extra Time Needed To Do JiTT?}

A final consideration is time. Faculty juggling teaching, managing a research lab and writing grants, plus other university obligations often feel that they have little time to invest in modifying their teaching, particularly when excellence in teaching may not be rewarded as highly as excellence in research. However, as the primary mission of any university is to promote learning, courses characterized by a high rate of student success should be the goal. Fortunately, as described in Shaping the Future: New Expectations for Undergraduate Education in Science, Mathematics, Engineering, and Technology, many universities departments, deans, and faculty colleagues are realizing the need to increase the importance of teaching in the reward system for faculty who help students learn well (National Science Foundation, 1996).

JiTT does take more time compared to the way a traditional large enrollment lecture-based class is usually managed. However, we stress again that faculty can tailor any of the following aspects of JiTT to best meet their own course needs and make the most value of the additional time input needed. Web-based Warm Up and Good For assignments that come in just once per week require only an hour of two of faculty time, but have the value of identifying a large body of prior knowledge from perhaps hundreds of students at a time that can be used to inform teaching and learning. Cooperative Learning exercises may take time 'away' from traditional lecture, but have the advantage of requiring students to work in a cooperative, active learn- 
ing atmosphere, getting practice with working directly with data analysis and confronting any difficulties they may be having with the course material while they are in class with faculty help available. In addition, they have the advantage of greatly improving classroom attendance, which can be very poor in many traditional classes.

A final comment about time needed for grading: We recommend that faculty take full advantage of course management features like automatic grading of Web-based assignments into the course gradebook, so that valuable time does not have to be spen tentering student scores manually into a spreadsheet. If grades must be computed or entered manually (as with Cooperative Learning exercises), a student grader employed for an hour or two a week can take care of all of the grading used in JiTT. The most important goal, however, regardless of how many of the features of JiTT are used, is to engage the students and help them achieve mastery of the subject through active learning, constructivism, and prompt feedback. JiTT courses do require faculty to invest a bit more time than they might in a traditional lecture class, but the investment of time pays off in that faculty are using strategies that are strongly recommended from research on learning by the National Science Foundation, AAAS, and other national organizations for effective undergraduate teaching, resulting in increased student gains and a more interactive classroom experience for faculty and students alike.

\section{ACCESSING MATERIALS}

Electronic materials discussed in this paper include the following:

Contemporary Biology Web site (http://www.biology. iupui.edu/biocourses N100/

Biotechnology Web site (http://www.biology.iupui.edu / biocourses/Biol540/)

Just-in-Time Teaching Web site (http://webphysics. iupui.edu/jitt/itt.html)

The Web Science Project at IUPUI (http://webphysics. iupui.edu/webscience/webscience.html)

Contemporary Biology JiTT resource page (http:// www.biology.iupui.edu/biocourses $\mathbb{N} 100$ /archives.html)

Each of these Websites is available to the public, is not password-protected, and is available in standard HTML format. There are no restrictions on the use of materials on these Web pages by educators or by nonprofit institutions as long the content not modified and proper copyright acknowledgement is retained.

\section{ACKNOWLEDGEMENTS}

Support for the development of JiTT methods in Contemporary Biology and Biotechnology is provided by the National Science Foundation, Division of Undergraduate Education (NSF-DUE Award 9981111), to the Web Science Project at IUPUI.

\section{REFERENCES}

American Association for the Advancement of Science (1989). Project 2061 Science for All Americans, Rutherford F.J., and Ahlgren, A., eds. Washington, DC: Oxford University Press.
Arons, A.B. (1979). Some thoughts on reasoning capacities implicitly expected of college students, in Cognitive Process Instruction,Lochead, J. and Clement, J., eds. Philadelphia: Franklin Institute Press.

Astin, A.W. (1993). What Matters in College? Four Critical Years Revisited. New York: Jossey-Bass.

Bishop, B.A., and Anderson, C.W. (1990). Student Conceptions of Natural Selection and Its Role in Evolution. J. Res. Sci. Teach. 27, 415412.

Bybee, R., ed. (2002). Learning Science and the Science of Learning. Arlington VA: NSTA.

Bres, M., and Weisshaar, A. (2000) Cooperative Learning: Making Connections in General Biology. Pacific Grove, CA: Brooks/Cole ThompsonLearning.

Chickering, A.W., and Gamson, Z.F. (March 1987). Seven principles for good practice in undergraduate education. AAHE Bull. 3-7. http:/ aahebulletin.com/public/archive/sevenprinciples1987.asp (accessed November 15, 2003).

Chickering, A.W., and Ehrmann, S.C. (October 1996). Implementing the seven principles: technology as lever. AAHE Bull. October, 3-6. (accessed November 15, 2003).

Committee on Undergraduate Science Education (1997). Misconceptions as Barriers to Understanding Science. In: Science Teaching Reconsidered: A Handbook. Washington, DC: National Academy Press. (accessed November 15, 2003).

Dancy, M., and Beichner, R. (2002). But are they learning? Getting started in classroom evaluation. Cell Biol. Educ. 1, 87-94. (accessed November 15,2003).

de Caprariis, P., Barman, C., and Magee, P. (2001). Monitoring the benefits of active learning exercises in introductory survey courses in science: an attempt to improve the education of prospective public school teachers. J. Scholar. Teach. Learn. 1, 1-11.

Fisher, K.M., Lipson Joseph, I., Hildebrand, A.C., Miguel, L., Schoenberg, N., and Porter, N. (1986). Student misconceptions and teacher assumptions in college biology. J. Coll. Sci. Teach. 15(4), 276280.

Gavrin, A.D. and Novak, G. (1999). What is physics good for? Motivating Students with Online Materials. City: Publisher. (accessed November 15,2003).

Gavrin, A., Marrs, K., Blake, R., and Watt, J. (1999). The Web Science Project at IUPUI. (accessed November 15, 2003).

Hake, R.R. (1998). Interactive-engagement versus traditional methods: A six-thousand-student survey of mechanics test data for introductory physics courses. Am. J. Physics 66, 64-74.

Hake, R. (2002). Lessons from the physics education reform effort. Conserv. Ecol. 5, 28. (accessed November 15, 2003).

Haslam, F., and Treagust, D.F. (1987). Diagnosing secondary students' misconceptions of photosynthesis and respiration in plants using a two-tier multiple choice instrument. J. Biol. Educ. 21, 203-211.

Hazel, E., Prosser, M. (1994). First-year university students' understanding of photosynthesis, their study strategies and learning context. Am. Biol. Teach. 56, 274-279.

Heim, W.G. (1991). What is a recessive allele? Am. Biol. Teach. 53, 9497.

Hensen, M.S., and Finley, F.N. (1996). Changes in students' understanding of evolution resulting from different curricular and instructional strategies. J. Res. Sci. Teach. 33, 879-900.

Hestenes D., Wells M., and Swackhammer G. (1992). Force concept inventory. Physics Teach. 30(3), 141-158.

Holloway J.H. (2000). How does the brain learn science? Res. Link Educ. Leaders. 58, 85-86. (accessed November 15, 2003).

Hoover, J.P. (2002). A dozen ways to raise students' test performance. 
Principal 81, 17-18. (accessed November 15, 2003).

Jensen, M.S. (1996). A computer-assisted instruction unit on diffusion and osmosis with a conceptual change design. J. Comput. Math. Sci. Teach. 15, 49-64.

Kirkland, K., and Hollandsworth, J.G., Jr. (1979). Test anxiety, study skills, and academic performance. J. Coll. Stud. Person. 20, 431-435. (accessed November 15, 2003).

Klymkowsky, M.W., Garvin-Doxas, K., and Zeilik, M. (2003). Bioliteracy and teaching efficacy: what biologists can learn from physicists. Cell Biol. Educ. 2, 155-161. (accessed November 15, 2003).

Kujawa, S., and Huske, L. (1995). The Strategic Teaching and Reading Project Guidebook (rev. ed.). Oak Brook, IL: North Central Regional Educational Laboratory. (accessed November 15, 2003).

Lawson, A.E., and Thompson, L.D. (1988). Formal reasoning ability and misconceptions concerning genetics and natural selection. J. Res. Sci. Teach. 25, 733-746.

Ledder, G. (2002). Experiments in Improvement of Long-Term Learning. CITY?: Project Kaleidoscope Events. (accessed November 15,2003)

Longden, B. (1982). Genetics-are there inherent learning difficulties?" J. Biol. Educ. 16, 135-140.

Lord, T., and Marino, S. (1993). How university students view the theory of evolution. J. Coll. Sci. Teach. 22, 353-357.

Marrs K.A., Blake R., and Gavrin, A.D. (2003). Use of Warm Up exercises in Just in Time Teaching: determining students' prior knowledge and misconceptions in biology, chemistry, and physics. J. Coll. Sci. Teach.

Marrs, K.A. (2003). Just in Time Teaching enhances cognitive gains in biology.J. Coll. Sci. Teach.

National Research Council (1996). National Science Education Standards. Washington, DC: National Academy Press. (accessed November 15, 2003).

National Research Council (2000). How People Learn: Brain, Mind, Experience and School, Bransford, J.D., Brown, A.L., and Cocking, R.R., eds. Washington, D.C.: National Academy Press. (accessed November $15,2003)$
National Science Foundation Advisory Committee to the Directorate for Education and Human Resources (NSF-AC) (1996). Shaping the Future: New Expectations for Undergraduate Education in Science, Mathematics, Engineering, and Technology. Arlington, VA: National ScienceFoundation.

Novak, G, Patterson, E.T., Gavrin, A.D., and Christian, W. (1999). JustIn-Time Teaching: Blending Active Learning with Web Technology, Upper Saddle River, NJ: Prentice Hall.

Odom, A.L., Barrow, L.H. (1995). Development and application of a two-tier diagnostic test measuring college biology students' understanding of diffusion and osmosis after a course of instruction. J. Res. Sci. Teach. 32, 45-61.

Paulson, D.R. (1999). Active learning and cooperative learning in the organic chemistry lecture class. J. Chem. Educ. 76, 1136-1140. (Subscription required) (accessed November 15, 2003).

Roschelle, J. (1995). Learning in Interactive Environments: prior knowledge and new experience. In Falk, J.H. and Dierking, L.D., eds., In: Public Institutions for Personal Learning: Establishing a Research Agenda, pp. 37-51). Washington, DC: American Association of Museums. (accessed November 15, 2003).

Songer, C.J., and Mintzes, J.J. (1994). Understanding Cellular Respiration: An Analysis of Conceptual Change in College Biology, J. Res.Sci. Teach. 31, 621-637.

Tanner, K, Liesl, S., Chatman, L.S., and Allen D. (2003). Approaches to cell biology teaching: cooperative learning in the science classroombeyond students working in groups. Cell Biol. Educ. 2, 1-5. (accessed November 15,2003).

Udovic, D., Morris, D., Dickman, A., Postlethwait, J., and Wetherwax, P. (2002). Workshop Biology: demonstrating the effectiveness of active learning in an introductory biology course. BioScience 52, 272-281. (Subscription required) (accessed November 15, 2003).

Westbrook, S.L., and Marek, E.A. (1991). A cross-age study of student understanding of the concept of diffusion. J. Res. Sci. Teach. 28, 649660. 